\title{
Short communication: Circulating and milk adiponectin change differently during energy deficiency at different stages of lactation in dairy cows
}

\author{
S. P. Singh, ${ }^{\star}$ S. Häussler, ${ }^{* 1}$ J. J. Gross, † F. J. Schwarz,ł R. M. Bruckmaier, † and H. Sauerwein* \\ *Institute of Animal Science, Physiology and Hygiene Unit, University of Bonn, 53115 Bonn, Germany \\ †Veterinary Physiology, Vetsuisse Faculty, University of Bern, Bremgartenstr. 109a, CH-3001 Bern, Switzerland \\ ‡Department of Animal Sciences, Animal Nutrition, Technical University of Munich, Liesel-Beckmann-Str. 6, D-85350 Freising-Weihenstephan, \\ Germany
}

\section{ABSTRACT}

Adiponectin, one of the most abundant adipokines in circulation, is known for its role in regulation of body metabolism. The aim of this study was to evaluate the effects of a negative energy balance (NEB) at 2 stages of lactation (lactational NEB at the onset of lactation and an induced NEB by feed restriction near $100 \mathrm{~d}$ of lactation) on circulating adiponectin concentrations. We also investigated the effect of feed restriction on adiponectin concentrations in milk and the relationships of blood and milk adiponectin with selected plasma or milk variables and with measures of body condition. Plasma adiponectin was measured in 50 multiparous Holstein dairy cows throughout 3 experimental periods [i.e., period $1=3 \mathrm{wk}$ antepartum up to $12 \mathrm{wk}$ postpartum, period $2=3$ wk of feed restriction starting at around $100 \mathrm{~d}$ in milk with a control $(\mathrm{n}=25)$ and feed-restricted group ( $50 \%$ of energy requirements; $\mathrm{n}=$ 25 ), and period $3=$ subsequent realimentation period for $8 \mathrm{wk}$. Milk adiponectin was investigated among 21 multiparous cows at wk 2 and wk 12 of period 1 and wk 2 of period 2. Adiponectin concentrations in plasma and skim milk were measured using an in-house ELISA specific for bovine adiponectin. Major changes in circulating adiponectin concentrations were observed during the periparturient period, whereas energy deficiency during established lactation at around $100 \mathrm{~d}$ in milk and subsequent refeeding did not affect plasma adiponectin. Together with lower adiponectin concentrations in milk $(\mu \mathrm{g} / \mathrm{mL})$, the reduction in milk yield led to decreased adiponectin secretion via milk $(\mathrm{mg} / \mathrm{d})$ at the second week of feed restriction. Irrespective of time and treatment, milk adiponectin represented about $0.002 \%$ of total milk protein. Mean adiponectin concentrations in milk $(0.61 \pm 0.03 \mu \mathrm{g} / \mathrm{mL})$ were about $92 \%$ lower than the mean plasma adiponectin concentrations (32.1 $\pm 1.0 \mu \mathrm{g} / \mathrm{mL}$ ). The proportion of the steady-state

Received October 14, 2013.

Accepted December 3, 2013.

${ }^{1}$ Corresponding author: susanne.haeussler@uni-bonn.de plasma adiponectin pool secreted daily via milk was $2.7 \%$. In view of the similar extent of NEB in both periods of energy deficiency, decreasing adiponectin concentrations seems important for accomplishing the adaptation to the rapidly increasing metabolic rates in early lactation, whereas the lipolytic reaction toward feed restriction-induced NEB during established lactation seems to occur largely independent of changes in circulating adiponectin.

Key words: adiponectin, milk, energy deficiency, dairy cow

\section{Short Communication}

With the onset of lactation in high-producing dairy cows, milk synthesis leads to an approximately 4-fold increase in total energy requirements compared with pregnant and nonlactating state (Block et al., 2001), which is often accompanied by insufficient voluntary feed intake. The period of negative energy balance (NEB) is associated with changes in several metabolic key hormones, such as growth hormone and IGF-1, and the responsiveness of peripheral tissues for these hormones (Rhoads et al., 2007). The period of energy demand such as early lactation in dairy cattle is characterized by an increase in lipolysis and a decrease in lipogenesis (McNamara and Hillers, 1986). During lipolysis, FA in the form of NEFA are released from adipose tissue (AT) and serve as a major energy substrate for body tissues.

Adipose tissue is not only an energy storage organ, but also synthesizes and secretes a wide range of metabolically active hormones, proteins, and other bioactive molecules, collectively termed as adipokines (Kershaw and Flier, 2004). Changes in metabolic activities of AT during the period of NEB may affect the expression of adipokines and vice versa (e.g., energy deficiency in periparturient cows reduce leptin gene expression and its plasma concentrations; Block et al., 2001).

Produced mainly by AT, adiponectin - one of the most abundant adipokines in circulation - is known to 
be involved in regulation of glucose and FA metabolism (Yamauchi et al., 2002). Studies about the concentration of adiponectin in bovine body fluids have been impeded by the lack of inexpensive, straightforward, and reliable assays for bovine adiponectin. Using semiquantitative Western immunoblotting the circulating adiponectin concentrations in dairy cows were recently characterized and were shown to be lowest during the periparturient period (Giesy et al., 2012; Mielenz et al., 2013). Using an ELISA system we recently developed specifically for bovine adiponectin, this time course was confirmed (Mielenz et al., 2013) and supports that adiponectin participates in coordinating the metabolic changes during the period of NEB in early lactation.

In rats, short-term (48-h) dietary fasting (no feed) decreased and refeeding increased adiponectin gene expression in perirenal AT (Zhang et al., 2002) as well as in subcutaneous and epididymal AT (Bertile and Raclot, 2004). However, the influence of feed restriction or complete feed deprivation on circulating adiponectin remains obscure, as previous rodent studies have reported contradictory findings with unchanged (after $48 \mathrm{~h}$ of fasting; Zhang et al., 2002), decreased (after $8 \mathrm{~h}$ of fasting and remaining constant thereafter until 48 h; Gui et al., 2003), or increased (after feed restriction of $60 \%$ of the baseline intake; Combs et al., 2003) adiponectin blood concentrations.

Changes in milk concentration of hormones and metabolites might reflect variations in their blood concentrations. Earlier reports suggest that the induced NEB by feed restriction in dairy cows alters milk yield and its composition such as fat and protein percentage (Gross et al., 2011a) or BHBA and citrate concentration (Nielsen et al., 2003). The objectives of the present study were to investigate the effect of lactational versus feed restriction induced NEB on plasma and milk adiponectin concentrations and their relationship with circulating concentrations of metabolic hormones such as leptin and insulin; variables linked to the fat metabolism such as NEFA and BHBA concentrations, and other variables such as revised quantitative insulin sensitivity check index, DMI, BW, BCS, back fat thickness (BFT), and energy balance.

The animal trial was conducted at the Agricultural Experimental Unit Hirschau of the Technical University of Munich (Freising-Weihenstephan, Germany) and was approved by the state department for animal welfare affairs. The animal experiment and feeding regimen was described in detail previously (Gross et al., 2011a). Briefly, the study included 50 multiparous Holstein dairy cows $(3.2 \pm 0.2$ lactations; mean \pm SEM $)$ from wk 3 antepartum (a.p.) to approximately wk 26 postpartum (p.p.). Period 1 was from wk 3 a.p. to wk 12 p.p., where all animals were treated as 1 group. The restriction phase (period 2) started at $98 \pm 7$ DIM and lasted for $3 \mathrm{wk}$. In this period, animals were allocated equally to either a control group $(\mathbf{C} ; \mathrm{n}=25)$ or a restriction group $(\mathbf{R} ; \mathrm{n}=25)$. The week before the start of the feed restriction was considered as wk 0 , when all animals were treated as 1 group. Calculations for dietary requirement of energy and protein followed the recommendations of the Society of Nutrition Physiology (GfE, 2001). At the start of period 2, an energy deficiency of approximately $50 \%$ of cow requirements was induced by feeding $\mathrm{R}$ cows a diet with a lower energy content (6.24 vs. $6.53 \mathrm{MJ}$ of $\mathrm{NE}_{\mathrm{L}} / \mathrm{kg}$ of $\mathrm{DM}$ ) compared with the $\mathrm{C}$ cows and a decreased amount of concentrate $(0.4 \mathrm{~kg}$ of $\mathrm{DM} / \mathrm{d}$, whereas $\mathrm{C}$ cows received concentrate according to the individual requirements for milk production). After 3 wk of feed restriction, period 3 (8 wk duration) started, during which $\mathrm{R}$ cows were (re)fed to the level of the $\mathrm{C}$ cows (realimentation period).

Blood samples $(n=50)$ were collected weekly via jugular vein puncture in $\mathrm{K}_{3}$ EDTA-coated (18-mL) evacuated blood collection tubes (Greiner Bio-One GmbH, Frickenhausen, Germany). Plasma samples were obtained by centrifugation $(2,000 \times g$ for $15 \mathrm{~min}$ at $4^{\circ} \mathrm{C}$ ) and stored at $-20^{\circ} \mathrm{C}$ until analyzed. Cows were milked twice daily at 0500 and $1500 \mathrm{~h}$ and daily milk yield was recorded electronically. Milk samples $(\mathrm{n}=21)$ at 2 consecutive milkings were collected at wk 2 and 12 (period 1) and wk 2 of the energy restriction period (period 2) for adiponectin analysis. Milk samples were vortexed properly to ensure sample uniformity before skimmed by centrifugation $(3,000 \times g$ for $30 \mathrm{~min}$ at $4^{\circ} \mathrm{C}$ ). Skim milk was harvested between the supernatant (fat layer) and the pellet (debris and cells) and stored at $-20^{\circ} \mathrm{C}$ until analysis.

Plasma and skim milk samples were analyzed for adiponectin using an in-house competitive ELISA, as described in detail earlier (Mielenz et al., 2013). Before measurement of milk adiponectin, assay accuracy was confirmed by linearity and parallelism of diluted milk samples. The measuring range of the assay was 0.07 to $1.00 \mathrm{ng} / \mathrm{mL}$ and the limit of detection was $0.03 \mathrm{ng} / \mathrm{mL}$. The intra- and interassay coefficients of variation for skim milk were 5 and $12 \%$, respectively.

The profiles of other variables such as NEFA, BHBA, DMI, BW, energy balance, BCS, BFT, and milk yield (Gross et al., 2011a), and revised quantitative insulin sensitivity check index, insulin, and leptin (Gross et al., 2011b) have been published elsewhere. In the current paper, the values were used to calculate the potential association with plasma and milk adiponectin concentrations.

Assuming that all milk adiponectin is derived from the circulation, the following calculations were done 
to estimate the proportion (\%) of steady-state plasma adiponectin pool secreted daily via milk:

- Total blood volume of a cow $(\mathrm{mL})=\mathrm{BW}(\mathrm{kg}) \times$ 57 (Hansard et al., 1953);

- Plasma volume $(\mathrm{mL})=$ blood volume $(\mathrm{mL}) \times$ 0.658 (Jones et al., 1956);

- Amount of adiponectin present in circulation (mg) $=$ plasma adiponectin concentration $(\mathrm{mg} / \mathrm{mL}) \times$ plasma volume $(\mathrm{mL})$;

- Amount of adiponectin secreted via milk $(\mathrm{mg})=$ milk adiponectin concentration $(\mathrm{mg} / \mathrm{L}) \times$ milk yield (L);

Proportion of steady-state plasma adiponectin secreted via milk (\%) $=\frac{\text { amount of adiponectin secreted via milk }(\mathrm{mg})}{\text { amount of adiponectin present in circulation }(\mathrm{mg})} \times 100$.

All statistical analyses were performed using SPSS (version 19.0; SPSS Inc., Chicago, IL). Data were tested for normal distribution using the Shapiro-Wilk test and homogeneity of variances was tested using Levene's test. A one-way repeated-measures ANOVA, followed by Bonferroni post hoc test was conducted for multiple comparisons of plasma adiponectin concentrations at different time points during period 1. During periods 2 and 3, plasma adiponectin concentrations between $\mathrm{C}$ and $\mathrm{R}$ groups were compared with the linear mixedmodel procedure, followed by Bonferroni correction. The model included individual animal as a repeated subject, and week, treatment, and their interaction as fixed effects. Milk adiponectin concentrations, adiponectin secretion, and proportion of steady-state plasma adiponectin secreted daily in periods 1 and 2 were compared by Student's $t$-test. The Pearson correlation coefficient was calculated for statistical analysis of relationships among variables. All data are presented as means \pm standard error of the mean. Significance was declared for $P<0.05$ and a trend was noted at $P \leq$ 0.10 .

Time-dependent changes in plasma adiponectin concentrations during different experimental periods are shown in Figure 1. Plasma adiponectin decreased from wk 3 a.p. and reached the lowest concentrations at the time of parturition; thereafter, the concentration increased gradually and approached a.p. values (3 wk a.p.) within 3 wk of lactation. The time- and treatmentdependent changes in milk adiponectin concentration and daily milk adiponectin secretion are presented in Figure 2. Both the milk adiponectin concentration and the daily milk adiponectin secretion were substantially higher in wk 2 than in wk 12 p.p. The induced feed restriction in period 2 led to a $21.9 \%$ decrease in the adiponectin milk secretion compared with the $\mathrm{C}$ group, although the milk adiponectin concentration only tended to be decreased in the $\mathrm{R}$ group.

When normalized to the amount of milk protein content, the mean milk adiponectin concentration was 18.5 $\pm 0.9 \mathrm{ng} / \mathrm{mg}$ of milk protein. Irrespective of time and treatment, milk adiponectin represented about $0.002 \%$ of total milk protein. The mean adiponectin concentration in milk $(0.6 \pm 0.03 \mu \mathrm{g} / \mathrm{mL})$ was $98.1 \%$ lower than the mean plasma adiponectin concentration $(32.1 \pm 1.0$ $\mu \mathrm{g} / \mathrm{mL}$ ). Considering all time points (wk 2 and 12 of period 1 and wk 2 of period 2), $2.7 \%$ of circulating adiponectin was secreted through milk per day. The proportions of circulating steady-state adiponectin secreted through milk in different periods are presented in Figure 3. The proportion was about twice as high in wk 2 as in wk 12 p.p. After the induced feed restriction, the proportion of steady-state adiponectin secreted through milk was significantly decreased (around 21.9\% decrease). Neither the plasma nor the milk adiponectin concentration was correlated with the milk yield. No significant association of plasma and milk adiponectin with plasma leptin and growth hormone was observed. The coefficients of correlation between plasma and milk adiponectin concentrations and adiponectin secretion with plasma, milk, and other variables are presented in Tables 1 and 2.

The transition from late gestation to lactation is a period of comprehensive physiological and metabolic adaptations to accomplish the nutrient demand of the mammary gland for milk production. Adiponectin is known to be involved in regulating glucose and FA metabolism (Yamauchi et al., 2002); therefore, adiponectin concentrations are likely to change during this period of NEB. We observed decreased plasma adiponectin concentrations from 3 wk a.p. to parturition and subsequently gradually increased concentrations rebounding over the next 4 wk of lactation. Similar characteristic patterns of peripartal changes of circulating adiponectin were recently characterized in dairy cows using semiquantitative Western immunoblotting (Giesy et al., 2012; Mielenz et al., 2013) and the ELISA used herein (Mielenz et al., 2013). Ruminants largely depend on gluconeogenesis for their glucose requirements; therefore, efficient gluconeogenesis in dairy cows is the major pathway for maintaining an adequate glucose supply for the mammary gland (Reynolds et al., 1988). Adiponectin increases glucose uptake and lactate production in skeletal muscle and reduces the expression of molecules involved in gluconeogenesis in liver (Yamauchi et al., 2002) and, thus, suppresses hepatic glucose production (Zhou et al., 2005). Furthermore, adiponectin is known to improve insulin sensitivity (Yamauchi et al., 2001). Together with decreasing insulin sensitivity in peripheral tissue, decreasing adiponectin 


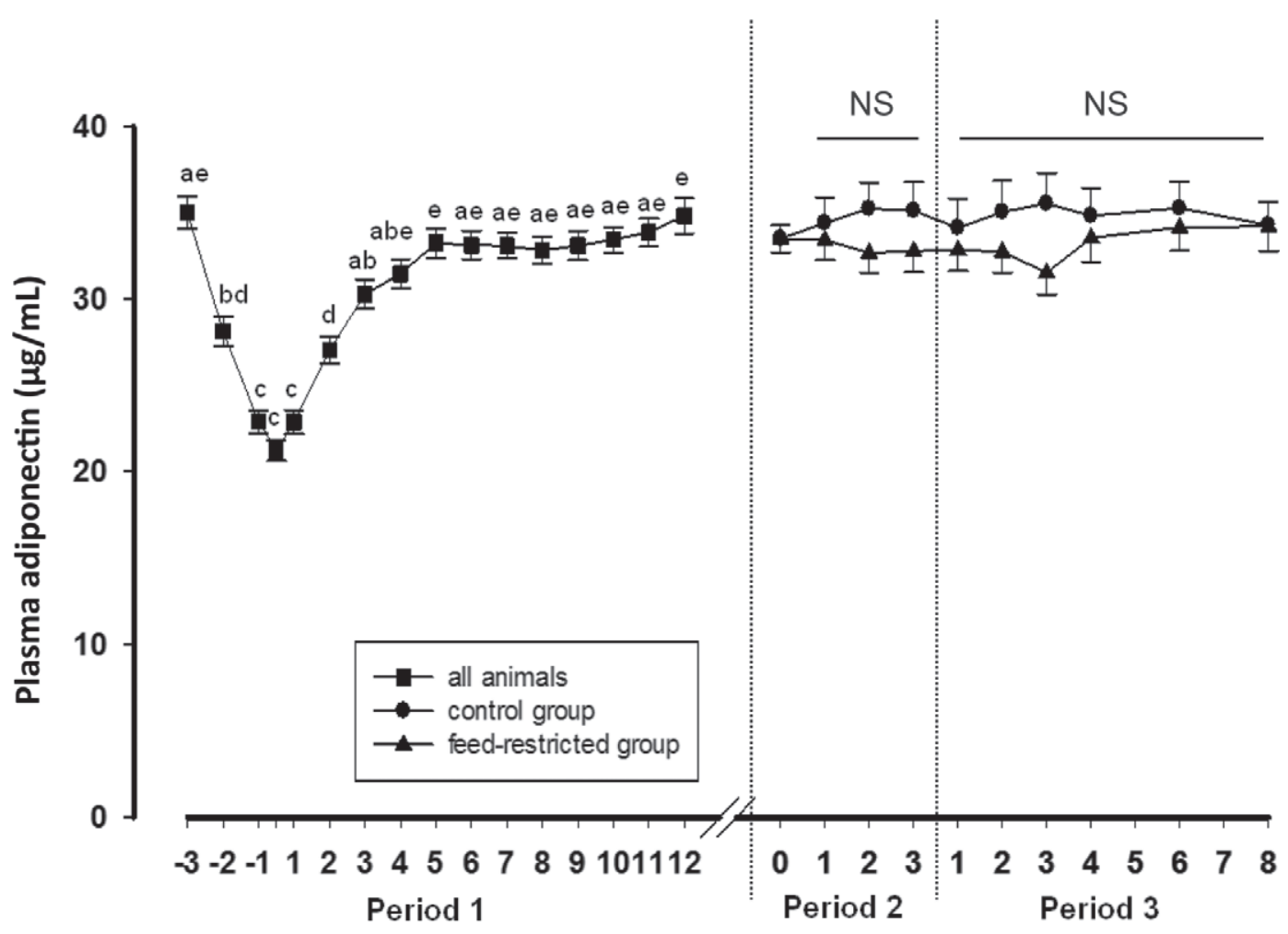

Experimental period (wk)

Figure 1. Plasma adiponectin concentration $(\mu \mathrm{g} / \mathrm{mL})$ in cows $(\mathrm{n}=50)$ during the experimental period 1 (from wk 3 antepartum to wk 12 postpartum), period 2 (3 wk of feed restriction, starting at about $100 \mathrm{DIM}$ ), and period 3 ( 8 wk of realimentation). Data are given as mean \pm SEM. Significant differences $(P<0.05)$ between the time points during period 1 are indicated by different lowercase letters $(\mathrm{a}-\mathrm{e}$; one-way repeated measure ANOVA, followed by the Bonferroni post hoc test). NS = no significant differences (linear mixed model) between the control $(\mathrm{n}=25)$ and feed-restricted $(\mathrm{n}=25)$ groups.

concentrations may support partitioning of glucose toward the mammary gland. A shift from circulating adiponectin toward the milk might explain the highest milk adiponectin concentrations along with low plasma adiponectin concentrations at wk 2 p.p. Although it is suggested that circulating adiponectin is unlikely to be a major source for milk adiponectin in humans (Ozarda et al., 2012), in the present study, a significant negative correlation of serum adiponectin concentration with milk adiponectin concentration was observed. However, whether adiponectin concentrations in milk are solely the source of plasma adiponectin or produced by the mammary gland itself needs to be investigated. Moreover, decreasing adiponectin concentrations might increase hepatic gluconeogenesis to improve glucose supply to the mammary gland for milk production. The precise functional importance of the periparturient reduction of circulating adiponectin in dairy cows remains to be characterized.

We did not observe significant effects of feed restriction and subsequent realimentation on plasma adipo- nectin concentrations, even though the extent of NEB was lower than that observed at the time of initiation of lactation (Gross et al., 2011a). The unchanged plasma adiponectin in $\mathrm{R}$ cows compared with the $\mathrm{C}$ cows indicates that its circulating concentration is not affected by energy balance. The finding of unchanged adiponectin concentrations during feed restriction agrees with results of energy restriction (4 d) study in humans (Imbeault et al., 2004) and total feed deprivation studies in rodents (48 h of fasting; Combs et al., 2003; Kmiec et al., 2005) and humans (48 to $72 \mathrm{~h}$ of fasting; Gavrila et al., 2003; Merl et al., 2005). However, another report suggests that adiponectin concentration is decreased in mice after $8 \mathrm{~h}$ of fasting (Gui et al., 2003). The discrepancy in these results might be due to age, physiological state, extent, and duration of fasting and (or) species differences.

From wk 2 to 12 p.p., milk adiponectin concentrations and adiponectin secretion decreased 46.2 and $44 \%$, respectively. In contrast, earlier human studies reported either unchanged (Bronsky et al., 2011) or 


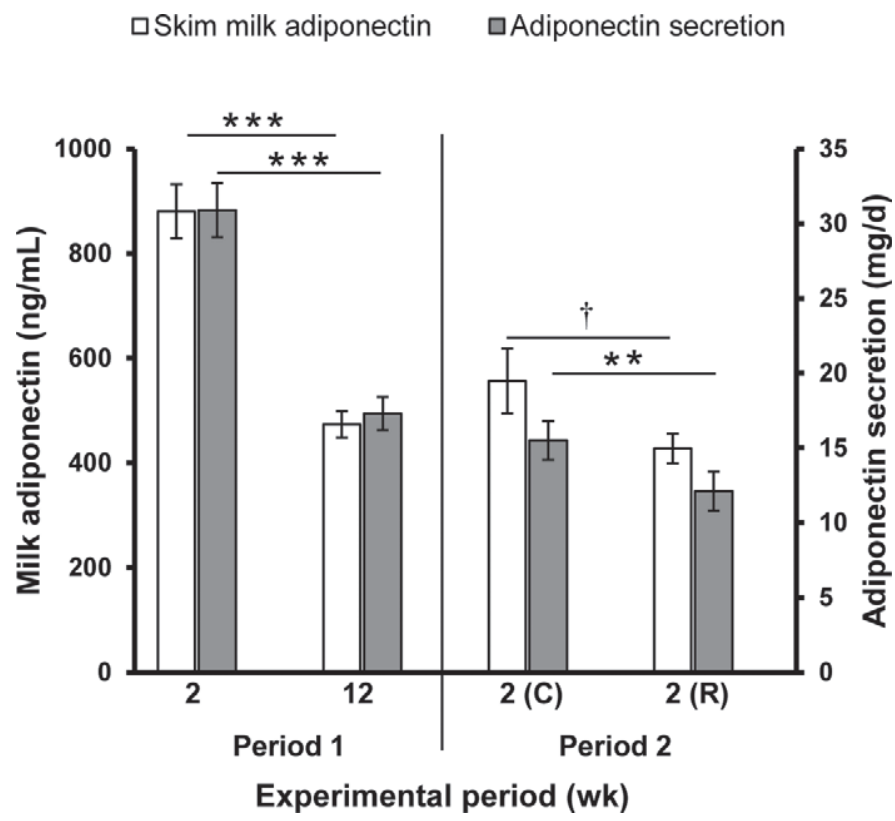

Figure 2. Skim milk adiponectin concentration $(\mathrm{ng} / \mathrm{mL})$ and adiponectin secretion via milk $(\mathrm{mg} / \mathrm{d})$ at wk 2 and 12 of period $1(\mathrm{n}=21)$ and control $(\mathrm{C} ; \mathrm{n}=11)$ and feed-restricted $(\mathrm{R} ; \mathrm{n}=10)$ groups at wk 2 of period 2. Data are given as mean \pm SEM. Significant differences are presented as ${ }^{* * *} P<0.001$ and ${ }^{* *} P<0.01$, and trends as $\dagger P<$ 0.10 (Student's $t$-test).

increased milk adiponectin concentrations during the first $180 \mathrm{~d}$ after birth (Ozarda et al., 2012). The milk yield of the animals in the present study was similar at wh 2 and 12, as reported in our previous study (Gross et al., 2011a); therefore, the observed decrease in adiponectin secretion in period 1 resulted from decreased milk adiponectin concentration. In period 2 , we observed a trend toward reduced adiponectin concentrations in milk in the $\mathrm{R}$ group compared with the $\mathrm{C}$ group. In addition, milk yield was significantly reduced in the $\mathrm{R}$ group during this period (Gross et al., 2011a); therefore, the reduction in both milk adiponectin concentration and milk yield led to decreased adiponectin secretion in $\mathrm{R}$ cows.

The rates of synthesis and clearance determine the blood concentration of hormones and metabolites. Adiponectin secretion rates from human adipocytes play only a minor role in the variation of its blood concentrations (Hoffstedt et al., 2004). Moreover, the liver-mediated clearance rate of adiponectin in mice is relatively stable (half-life $\sim 75 \mathrm{~min}$ ) and was not affected by $24 \mathrm{~h}$ of fasting (Halberg et al., 2009). The decrease in adiponectin secretion through milk during the period of feed restriction might provide an additional mechanism to prevent a significant decrease in its plasma concentrations during this period. Compared with the

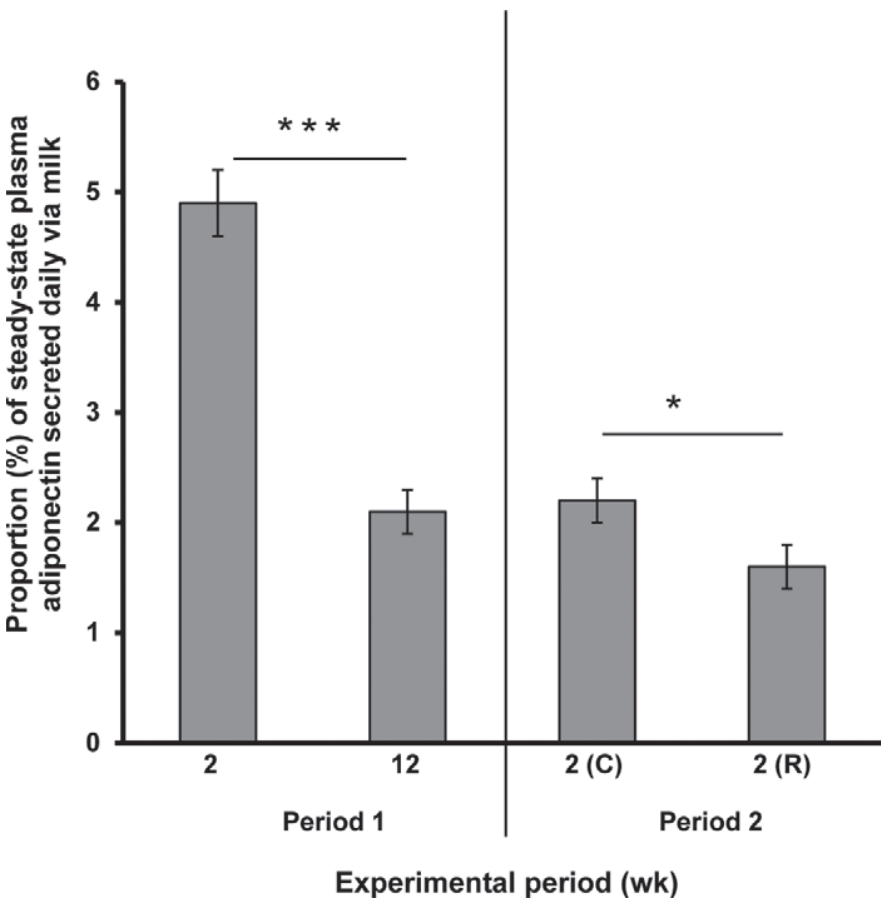

Figure 3. Proportion (\%) of steady-state plasma adiponectin pool secreted daily via milk at wk 2 and 12 of period $1(\mathrm{n}=21)$ and control $(\mathrm{C} ; \mathrm{n}=11)$ and feed-restricted $(\mathrm{R} ; \mathrm{n}=10)$ groups at wk 2 of period 2 . Data are given as mean \pm SEM. Significant differences are presented as ${ }^{* * *} P<0.001$ and ${ }^{*} P<0.05$ (Student's $t$-test).

concentration of leptin in milk that is around $6 \mathrm{ng} / \mathrm{mL}$ (Pinotti and Rosi, 2006), the mean milk adiponectin concentration observed herein $(616.4 \pm 32.6 \mathrm{ng} / \mathrm{mL})$ was about 100-fold higher, suggesting that, similar to the blood concentrations, adiponectin in milk is present in much higher concentration than other adipokines.

In humans and in animals such as horses, adiponectin mRNA expression and serum concentrations are decreased with an increased portion of body fat (Kern et al., 2003; Kearns et al., 2006). In dairy cows, an increase in fat mass could be expected with improvement in the body condition measures, such as BW, BCS, and BFT. This might explain the observed negative correlations of plasma adiponectin with measures of body condition (BW, BCS, and BFT) in the present study. The positive correlation between plasma adiponectin and insulin concentrations might indicate that the adiponectin secretion by adipocytes is stimulated by insulin (Blümer et al., 2008). Moreover, inhibitory effects of adiponectin on lipolysis (Qiao et al., 2011) or stimulatory effects on FA oxidation in liver and muscles (Yamauchi et al., 2002), or both, could explain the inverse association between adiponectin and NEFA observed in the current study. Adiponectin might increase DMI via stimulating the hypothalamic AMP- 
Table 1. Pearson correlation coefficients between plasma adiponectin $(\mu \mathrm{g} / \mathrm{mL})$ and plasma, milk, and other variables $(\mathrm{n}=50)^{1}$

\begin{tabular}{|c|c|c|c|c|c|c|c|}
\hline Variable $^{2}$ & \multicolumn{3}{|c|}{ Period $1^{3}$} & \multicolumn{2}{|c|}{ Period $2^{4}$} & Period 3 & $\begin{array}{c}\text { Entire } \\
\text { duration }^{5}\end{array}$ \\
\hline \multicolumn{8}{|l|}{ Plasma variable } \\
\hline $\mathrm{NEFA}^{6}(\mathrm{mmol} / \mathrm{L})$ & & $-0.225^{* * *}$ & $-0.148^{* * *}$ & $0.227^{*}$ & & & $-0.190^{* * *}$ \\
\hline $\mathrm{BHBA}^{6}(\mathrm{mmol} / \mathrm{L})$ & $-0.315^{* * *}$ & & & & & & \\
\hline Insulin $^{7}(\mu \mathrm{U} / \mathrm{mL})$ & & $0.219^{* * *}$ & $0.208^{* * *}$ & $0.365^{* * *}$ & & & $0.226^{* * *}$ \\
\hline \multicolumn{8}{|l|}{ Milk variable 6} \\
\hline Milk fat $(\%)$ & & & $-0.290 \dagger$ & & $-0.777^{* *}$ & & $-0.283^{*}$ \\
\hline Milk protein (\%) & & & $-0.366^{*}$ & & & & $-0.355^{* *}$ \\
\hline \multicolumn{8}{|l|}{ Other variables } \\
\hline RQUICKI $^{7}$ & & $0.111 \dagger$ & & & & & \\
\hline $\mathrm{DMI}^{6}(\mathrm{~kg} / \mathrm{d})$ & & $0.313^{* * *}$ & $0.351^{* * *}$ & & $0.277^{*}$ & & $0.185^{* * *}$ \\
\hline $\mathrm{BW}^{6}(\mathrm{~kg})$ & $-0.17^{*}$ & & $-0.185^{* * *}$ & & $-0.258^{*}$ & & $-0.152^{* * *}$ \\
\hline $\mathrm{BCS}^{6}$ & $-0.395^{* * *}$ & $-0.357^{* * *}$ & $-0.402^{* * *}$ & & $-0.299^{* *}$ & $-0.313^{* * *}$ & $-0.374^{* * *}$ \\
\hline
\end{tabular}

${ }^{1}$ Period $1=3$ wk before calving to wk 12 of lactation; period $2=$ period of energy restriction (wk 15 to 17 of lactation); period $3=$ period of realimentation (wk 18 to 25 of lactation).

${ }^{2}$ RQUICKI $=$ revised quantitative insulin sensitivity check index; BFT $=$ back fat thickness; EB = energy balance.

${ }^{3}$ Before calving $=3$ wk before calving until calving; after calving = calving until wk 12 of lactation.

${ }^{4} \mathrm{C}=$ control; $\mathrm{R}=$ energy restriction.

${ }^{5}$ Three weeks before calving until the end of the experiment.

${ }^{6}$ Data presented previously (Gross et al., 2011a).

${ }^{7}$ Data presented previously (Gross et al., 2011b).

${ }^{8}$ All data at wk 2 and 12 of period 1 and wk 2 of period $2(\mathrm{n}=21)$ were used for analysis; correlation coefficients $>0.1$ with significant and trend associations are presented.

$\dagger P \leq 0.10 ; * P \leq 0.05 ; * * P \leq 0.01 ; * * * P \leq 0.001$

activated protein kinase, as reported in mice (Kubota et al., 2007). However, the precise role of adiponectin in regulation of feed intake in dairy cows warrants further investigation. The observation that plasma adiponectin and leptin were not correlated in the present study supports the notion that they independently regulate

Table 2. Pearson correlation coefficients of milk adiponectin concentration $(\mu \mathrm{g} / \mathrm{mL})$ and adiponectin secretion via milk $(\mathrm{mg} / \mathrm{d})$ with milk, plasma, and other variables ${ }^{1}$

\begin{tabular}{lcc}
\hline Variable $^{2}$ & $\begin{array}{c}\text { Milk } \\
\text { adiponectin }\end{array}$ & $\begin{array}{c}\text { Adiponectin } \\
\text { secretion }\end{array}$ \\
\hline $\begin{array}{l}\text { Milk variable } \\
\text { Milk yield (kg) }\end{array}$ & & $0.478^{* * *}$ \\
Milk fat (\%) & $0.466^{* * *}$ & $0.421^{* * *}$ \\
Milk protein (\%) & $0.322^{* *}$ & \\
Plasma and other variables & $-0.399^{* *}$ & $-0.282^{*}$ \\
Leptin $(\mathrm{ng} / \mathrm{mL})$ & $0.613^{* * *}$ & $0.683^{* * *}$ \\
NEFA $^{3}(\mathrm{mmol} / \mathrm{L})$ & $0.327^{* *}$ & $0.404^{* *}$ \\
$\mathrm{BHBA}^{3}(\mathrm{mmol} / \mathrm{L})$ & $-0.493^{* * *}$ & $-0.470^{* * *}$ \\
$\mathrm{Glucose}^{3}(\mathrm{mmol} / \mathrm{L})$ & $-0.431^{* * *}$ & $-0.462^{* * *}$ \\
$\mathrm{RQUICKI}^{4}$ & & $0.422^{* * *}$ \\
$\mathrm{BW}^{3}(\mathrm{~kg})$ & $0.283^{*}$ & $0.397^{* * *}$ \\
$\mathrm{BCS}^{3}$ & & $0.343^{* * *}$ \\
$\mathrm{BFT}^{3}(\mathrm{~mm})$ & $-0.304^{* *}$ & $-0.354^{* *}$ \\
$\mathrm{~EB}^{3}(\mathrm{MJ}$ of NE$/ \mathrm{d})$ & & \\
\hline
\end{tabular}

${ }^{1}$ Data at wk 2 and 12 of period 1 and wk 2 of period 2 were used for analysis $(n=21)$. Correlation coefficients $>0.1$ with significant associations are presented.

${ }^{2}$ RQUICKI $=$ revised quantitative insulin sensitivity check index; BFT = back fat thickness; $\mathrm{EB}=$ energy balance.

${ }^{3}$ Data presented previously (Gross et al., 2011a).

${ }^{4}$ Data presented previously (Gross et al., 2011b).

${ }^{*} P \leq 0.05 ;{ }^{* *} P \leq 0.01 ; * * * \leq 0.001$. 
biological functions in the body, such as insulin sensitivity (Koebnick et al., 2008).

To summarize, our data showed that the most prominent changes in plasma adiponectin occur around parturition. Feed restriction and subsequent realimentation did not affect its circulating concentrations; therefore, we assume that in early lactation, adiponectin is important to cope with the adaptation to the rapidly increasing metabolic rates. Several other factors and not only energy deficiency might affect circulating adiponectin concentrations around parturition. Feed restriction resulted in reduced adiponectin secretion via milk and tended to decrease milk adiponectin concentrations. The putative biological significance of milk adiponectin and its relationship with other milk hormones and metabolites still remains to be characterized.

\section{ACKNOWLEDGMENTS}

S. P. Singh is the recipient of an International Fellowship by the Indian Council of Agricultural Research (ICAR) at the University of Bonn (Bonn, Germany).

\section{REFERENCES}

Bertile, F., and T. Raclot. 2004. Differences in mRNA expression of adipocyte-derived factors in response to fasting, refeeding and leptin. Biochim. Biophys. Acta 1683:101-109.

Block, S. S., W. R. Butler, R. A. Ehrhardt, A. W. Bell, M. E. Van Amburgh, and Y. R. Boisclair. 2001. Decreased concentration of plasma leptin in periparturient dairy cows is caused by negative energy balance. J. Endocrinol. 171:339-348.

Blümer, R. M. E., C. P. van Roomen, A. J. Meijer, J. H. P. M. HoubenWeerts, H. P. Sauerwein, and P. F. Dubbelhuis. 2008. Regulation of adiponectin secretion by insulin and amino acids in 3T3-L1 adipocytes. Metabolism 57:1655-1662.

Bronsky, J., K. Mitrova, M. Karpisek, J. Mazoch, M. Durilova, B. Fisarkova, K. Stechova, R. Prusa, and J. Nevoral. 2011. Adiponectin, AFABP, and leptin in human breast milk during 12 months of lactation. J. Pediatr. Gastroenterol. Nutr. 52:474-477.

Combs, T. P., A. H. Berg, M. W. Rajala, S. Klebanov, P. Iyengar, J. C. Jimenez-Chillaron, M. E. Patti, S. L. Klein, R. S. Weinstein, and P. E. Scherer. 2003. Sexual differentiation, pregnancy, calorie restriction, and aging affect the adipocyte-specific secretory protein adiponectin. Diabetes 52:268-276.

Gavrila, A., J. L. Chan, N. Yiannakouris, M. Kontogianni, L. C. Miller, C. Orlova, and C. S. Mantzoros. 2003. Serum adiponectin levels are inversely associated with overall and central fat distribution but are not directly regulated by acute fasting or leptin administration in humans: Cross-sectional and interventional studies. J. Clin. Endocrinol. Metab. 88:4823-4831.

GfE (Society of Nutrition Physiology). 2001. Ausschuss für Bedarfsnormen der Gesellschaft für Ernährungsphysiologie. Nr. 8. Empfehlungen zur Energie- und Nährstoffversorgung der Milchkühe und Aufzuchtrinder (Recommendations of energy and nutrient supply for dairy cows and breeding cattle). DLG-Verlag, Frankfurt am Main, Germany.

Giesy, S. L., B. Yoon, W. B. Currie, J. W. Kim, and Y. R. Boisclair. 2012. Adiponectin deficit during the precarious glucose economy of early lactation in dairy cows. Endocrinology 153:5834-5844.

Gross, J., H. A. van Dorland, R. M. Bruckmaier, and F. J. Schwarz. 2011a. Performance and metabolic profile of dairy cows during a lactational and deliberately induced negative energy balance with subsequent realimentation. J. Dairy Sci. 94:1820-1830.

Gross, J., H. A. van Dorland, F. J. Schwarz, and R. M. Bruckmaier. 2011b. Endocrine changes and liver mRNA abundance of somatotropic axis and insulin system constituents during negative energy balance at different stages of lactation in dairy cows. J. Dairy Sci. 94:3484-3494.

Gui, Y., J. V. Silha, S. Mishra, and L. J. Murphy. 2003. Changes in adipokine expression during food deprivation in the mouse and the relationship to fasting-induced insulin resistance. Can. J. Physiol. Pharmacol. 81:979-985.

Halberg, N., T. D. Schraw, Z. V. Wang, J.-Y. Kim, J. Yi, M. P. Hamilton, K. Luby-Phelps, and P. E. Scherer. 2009. Systemic fate of the adipocyte-derived factor adiponectin. Diabetes 58:1961-1970.

Hansard, S. L., W. O. Butler, C. L. Comar, and C. S. Hobbs. 1953. Blood volume of farm animals. J. Anim. Sci. 12:402-413.

Hoffstedt, J., E. Arvidsson, E. Sjölin, K. Wåhlén, and P. Arner. 2004. Adipose tissue adiponectin production and adiponectin serum concentration in human obesity and insulin resistance. J. Clin. Endocrinol. Metab. 89:1391-1396.

Imbeault, P., M. Pomerleau, M. E. Harper, and E. Doucet. 2004. Unchanged fasting and postprandial adiponectin levels following a 4-day caloric restriction in young healthy men. Clin. Endocrinol. (Oxf.) 60:429-433.

Jones, W. G., C. D. Hughes, M. J. Swenson, and G. K. Underbjerg. 1956. Plasma prothrombin time and hematocrit values of blood of dairy cattle. Proc. Soc. Exp. Biol. Med. 91:14-18.

Kearns, C. F., K. H. McKeever, V. Roegner, S. M. Brady, and K. Malinowski. 2006. Adiponectin and leptin are related to fat mass in horses. Vet. J. 172:460-465.

Kern, P. A., G. B. Di Gregorio, T. Lu, N. Rassouli, and G. Ranganathan. 2003. Adiponectin expression from human adipose tissue: Relation to obesity, insulin resistance, and tumor necrosis factor- $\alpha$ expression. Diabetes 52:1779-1785.

Kershaw, E. E., and J. S. Flier. 2004. Adipose tissue as an endocrine organ. J. Clin. Endocrinol. Metab. 89:2548-2556.

Kmiec, Z., L. Pokrywka, G. Kotlarz, J. Kubasik, A. Szutowicz, and A. Mysliwski. 2005. Effects of fasting and refeeding on serum leptin, adiponectin and free fatty acid concentrations in young and old male rats. Gerontology 51:357-362.

Koebnick, C., C. K. Roberts, G. Q. Shaibi, L. A. Kelly, C. J. Lane, C. M. Toledo-Corral, J. N. Davis, E. E. Ventura, K. Alexander, M. J. Weigensberg, and M. I. Goran. 2008. Adiponectin and leptin are independently associated with insulin sensitivity, but not with insulin secretion or beta-cell function in overweight Hispanic adolescents. Horm. Metab. Res. 40:708-712.

Kubota, N., W. Yano, T. Kubota, T. Yamauchi, S. Itoh, H. Kumagai, H. Kozono, I. Takamoto, S. Okamoto, T. Shiuchi, R. Suzuki, H. Satoh, A. Tsuchida, M. Moroi, K. Sugi, T. Noda, H. Ebinuma, Y. Ueta, T. Kondo, E. Araki, O. Ezaki, R. Nagai, K. Tobe, Y. Terauchi, K. Ueki, Y. Minokoshi, and T. Kadowaki. 2007. Adiponectin stimulates AMP-activated protein kinase in the hypothalamus and increases food intake. Cell Metab. 6:55-68.

McNamara, J. P., and J. K. Hillers. 1986. Adaptations in lipid metabolism of bovine adipose tissue in lactogenesis and lactation. J. Lipid Res. 27:150-157.

Merl, V., A. Peters, K. M. Oltmanns, W. Kern, J. Born, H. L. Fehm, and B. Schultes. 2005. Serum adiponectin concentrations during a 72-hour fast in over- and normal-weight humans. Int. J. Obes. (Lond.) 29:998-1001.

Mielenz, M., B. Mielenz, S. P. Singh, C. Kopp, J. Heinz, S. Häussler, and H. Sauerwein. 2013. Development, validation, and pilot application of a semiquantitative Western blot analysis and an ELISA for bovine adiponectin. Domest. Anim. Endocrinol. 44:121-130.

Nielsen, N. I., K. L. Ingvartsen, and T. Larsen. 2003. Diurnal variation and the effect of feed restriction on plasma and milk metabolites in TMR-fed dairy cows. J. Vet. Med. A Physiol. Pathol. Clin. Med. 50:88-97.

Ozarda, Y., Y. Gunes, and G. O. Tuncer. 2012. The concentration of adiponectin in breast milk is related to maternal hormonal and 
inflammatory status during 6 months of lactation. Clin. Chem. Lab. Med. 50:911-917.

Pinotti, L., and F. Rosi. 2006. Leptin in bovine colostrum and milk. Horm. Metab. Res. 38:89-93.

Qiao, L., B. Kinney, J. Schaack, and J. Shao. 2011. Adiponectin inhibits lipolysis in mouse adipocytes. Diabetes 60:1519-1527.

Reynolds, C. K., G. B. Huntington, H. F. Tyrrell, and P. J. Reynolds. 1988. Net portal-drained visceral and hepatic metabolism of glucose, L-lactate, and nitrogenous compounds in lactating Holstein cows. J. Dairy Sci. 71:1803-1812.

Rhoads, R. P., J. W. Kim, M. E. Van Amburgh, R. A. Ehrhardt, S. J. Frank, and Y. R. Boisclair. 2007. Effect of nutrition on the GH responsiveness of liver and adipose tissue in dairy cows. J. Endocrinol. 195:49-58.

Yamauchi, T., J. Kamon, Y. Minokoshi, Y. Ito, H. Waki, S. Uchida, S. Yamashita, M. Noda, S. Kita, K. Ueki, K. Eto, Y. Akanuma, P. Froguel, F. Foufelle, P. Ferre, D. Carling, S. Kimura, R. Nagai, B. B. Kahn, and T. Kadowaki. 2002. Adiponectin stimulates glucose utilization and fatty-acid oxidation by activating AMP-activated protein kinase. Nat. Med. 8:1288-1295.

Yamauchi, T., J. Kamon, H. Waki, Y. Terauchi, N. Kubota, K. Hara, Y. Mori, T. Ide, K. Murakami, N. Tsuboyama-Kasaoka, O. Ezaki, Y. Akanuma, O. Gavrilova, C. Vinson, M. L. Reitman, H. Kagechika, K. Shudo, M. Yoda, Y. Nakano, K. Tobe, R. Nagai, S. Kimura, M. Tomita, P. Froguel, and T. Kadowaki. 2001. The fatderived hormone adiponectin reverses insulin resistance associated with both lipoatrophy and obesity. Nat. Med. 7:941-946.

Zhang, Y., M. Matheny, S. Zolotukhin, N. Tumer, and P. J. Scarpace. 2002. Regulation of adiponectin and leptin gene expression in white and brown adipose tissues: Influence of beta3-adrenergic agonists, retinoic acid, leptin and fasting. Biochim. Biophys. Acta 1584:115-122.

Zhou, H., X. Song, M. Briggs, B. Violand, W. Salsgiver, E. A. Gulve, and Y. Luo. 2005. Adiponectin represses gluconeogenesis independent of insulin in hepatocytes. Biochem. Biophys. Res. Commun. 338:793-799. 